\title{
The Effect of Environment on the Replication of Poliovirus in Monkey Kidney Cells
}

\author{
By G. FURNESS* \\ Department of Microbiology, University of Pittsburgh School of \\ Medicine, Pittsburgh, Pa.
}

(Received 18 January 1961)

\begin{abstract}
SUMMARY
Poliovirus can complete its maturation in monkey kidney cells suspended in semi-solid agar. Infectious particles and the progeny from each infected cell diffuse through the semi-solid agar to form a single plaque in an underlying monkey kidney cell monolayer. Using this technique, the effect of environment on the multiplication of poliovirus in singly infected monkey kidney cells was studied. Under optimal conditions of $\mathrm{pH}$ and temperature $\left(\mathrm{pH} 7 \cdot 0-7 \cdot 4,37^{\circ}\right)$ one-step growth curves indicated that over $95 \%$ of the adsorbed virus particles went into eclipse; that the eclipse phase lasted 3-4 hr.; that the increase in infective virus was exponential and that a yield of 700-1400 infectious particles/infected cell was obtained in 12-14 hr. After about $10 \%$ of the total progeny had formed, the cells began to release virus. Under suboptimal conditions of $\mathrm{pH}$ or temperature, the eclipse stage was prolonged. At pH 6.0-6.5 it lasted for $6 \mathrm{hr}$. and at $\mathrm{pH} 5 \cdot 0-5 \cdot 5$ for more than $9 \mathrm{hr}$. At $25^{\circ}$ virus particles were adsorbed and went into eclipse, with the exception of some particles which remained infectious and could be neutralized by antiserum. Thereafter the eclipse stage was strikingly prolonged, and replication proceeded on raising the temperature to $37^{\circ}$.
\end{abstract}

\section{INTRODUCTION}

One-step growth curves have been described for poliovirus multiplying in suspensions of HeLa cells (Dulbecco \& Vogt, 1955) and R.K. cells (Lwoff \& Lwoff, 1960) and in monolayers of monkey kidney cells (Howes \& Melnick, 1957; McLaren, Holland \& Syverton, 1959) and HeLa cells (Maassab, Loh \& Ackermann, 1957; Darnell, 1958; McLaren et al. 1959). The present paper reports an investigation of the effect of environmental conditions on the eclipse phase of poliovirus in monkey kidney cell suspensions studied by a technique in which not only the virus but also the infected cells could be titrated.

\section{METHODS}

Virus. A suspension of Type I poliovirus, Parker strain, grown in trypsindispersed monkey kidney cultures, was used.

Antiserum. This was prepared in rhesus monkeys; a 1/250 dilution of serum neutralized 30 infectious particles of the poliovirus suspension.

* Present address: The Lister Institute of Preventive Medicine, Chelsea Bridge Road, London, S.W. 1 . 
Monkey kidney monolayers. These were prepared from rhesus monkeys (Youngner, 1954) and cultivated in $6 \mathrm{~cm}$. Petri dishes.

Media. The following media, containing $100 \mu \mathrm{g}$. streptomycin $/ \mathrm{ml}$., 100 i.u. penicillin $/ \mathrm{ml}$. and 70 units (E. R. Squibb) mycostatin $/ \mathrm{ml}$. were used: (a) Hanks's solution containing $\mathbf{0 . 5} \%(\mathrm{w} / \mathrm{v})$ lactalbumin hydrolysate and $5 \%(\mathrm{v} / \mathrm{v})$ calf serum, adjusted to $\mathrm{pH} 7 \cdot 0-7 \cdot 4$ with $5 \%(\mathrm{w} / \mathrm{v}) \mathrm{NaHCO}_{3}$ solution. (b) Medium 199 supplied by Microbiological Associates, Bethesda, Maryland, U.S.A. (c) Agar overlay (Youngner, 1956).

Solutions. All sera were inactivated by heating for $30 \mathrm{~min}$. at $56^{\circ}$. Phosphate buffered (PB) saline without calcium and magnesium, and $0.2 \%(w / v)$ ethylenediaminetetra-acetic acid in PB saline (EDTA saline) were prepared according to Lwoff, Dulbecco, Vogt \& Lwoff (1955).

Disruption of cells. Monkey kidney cells suspended in tissue culture medium in rubber-stoppered cellulose nitrate tubes were disrupted by ultrasonic vibration at $9000 \mathrm{cyc} . / \mathrm{sec}$. for $10 \mathrm{~min}$. in a Raytheon $200 \mathrm{~W}$. $10 \mathrm{kcyc}$. magnetostrictive oscillator.

Assay of poliovirus infected cells and infectious particles. Poliovirus infected cells and infectious particles were titrated in monkey kidney cell monolayers. The monolayers were washed with serum-free medium and inoculated with $0.5 \mathrm{ml}$. of a suitable dilution of virus or infected cells mixed with $1 \mathrm{ml}$. overlay, the final concentration of agar in this thin covering layer being $0.6 \%$. After the mixture had solidified it was covered with a further $2 \mathrm{ml}$. overlay and the dishes incubated for 3 days at $37^{\circ}$ in air containing $5 \% \mathrm{CO}_{2}$. Not less than three samples were assayed from each dilution.

One-step growth curves. For poliovirus in suspensions of monkey kidney cells onestep growth curves were obtained as follows. A monkey kidney cell monolayer was washed twice in $\mathrm{PB}$ saline and infected with $0.5 \mathrm{ml}$. virus suspension, which was allowed to adsorb for $60 \mathrm{~min}$. at $25^{\circ}$ or $37^{\circ}$. The monolayer was freed from unadsorbed virus by washing 5 times with $\mathrm{PB}$ saline and separated into single cells by incubation with $3 \mathrm{ml}$. EDTA saline for $30 \mathrm{~min}$. at $37^{\circ}$. The EDTA saline suspension was inactivated with $7 \mathrm{ml}$. medium 199 and the suspension diluted $1 / 200$ in medium containing $2 \%(\mathrm{v} / \mathrm{v})$ inactivated monkey serum. To allow maturation of the virus, $100 \mathrm{ml}$. of diluted cell suspension were incubated in $250 \mathrm{ml}$. rubber stoppered siliconed flasks in a $37^{\circ}$ water bath and shaken every $30 \mathrm{~min}$. At intervals $0.5 \mathrm{ml}$. samples were assayed to determine the number of infected cells in the early stages of the experiment, and later the number both of infected cells and of virus progeny spontaneously released into the medium. A second sample ( $2 \mathrm{ml}$.) was assayed, after treatment with ultrasonic vibrations to release virus from the cells, to determine the total number of infectious particles. The number of intracellular infective virus was obtained by difference. After dilution the cell suspension contained about 2000 cells $/ \mathrm{ml}$., of which 60 were infected, thus virtually precluding early infection of cells by released virus progeny.

Unless otherwise stated, all media and solutions were kept at $\mathrm{pH} 7 \cdot 0-7 \cdot 4$ and at $37^{\circ}$. 


\section{RESULTS}

The same titre of $1 \cdot 2 \times 10^{7}$ infectious particles $/ \mathrm{ml}$. suspension was obtained when the pool of Parker type 1 poliovirus was assayed by the technique described and by the usual method (in which the inoculum is first adsorbed to the monkey kidney cell monolayers, Youngner, 1956), thus showing that all the virus diffused through the semi-solid agar. To ascertain whether the virus matured completely in single cells in suspension in semi-solid agar, a monolayer was inoculated with a dilution of the virus pool estimated to infect about 1000 cells. After it had adsorbed virus the monolayer was separated with EDTA saline and $0.5 \mathrm{ml}$. samples of the infected cell suspension, suitably diluted, were suspended in $1 \mathrm{ml}$. semi-solid agar for assay by the present technique. The titre of the virus pool estimated from the number of infected cells so determined was $1 \cdot 0 \times 10^{7}$ infectious particles. This value, within the limits of experimental error, is the same as the original titre; virus particles adsorbed to cells were capable of completing their replication to the point where the progeny of each cell diffused through the semi-solid agar in a close cluster to form a single plaque in the underlying monolayer.

\section{The influence of environment on the replication of poliovirus}

\section{The effect of temperature}

After adsorption at either $25^{\circ}$ or $37^{\circ}$ for $1 \mathrm{hr}$. about $70 \%$ of the adsorbed virus particles were in eclipse. The remainder were released as infectious particles on disintegrating the cells. At $25^{\circ}$ the number of infected cells and the proportion of virus which was not in eclipse remained constant for $10 \mathrm{hr}$. (Table 1), indicating

Table 1. Effect of incubation at $25^{\circ}$ on the survival and replication of poliovirus in suspension of monkey kidney cells at $\mathrm{pH} 7 \cdot 0-7 \cdot 4$

\begin{tabular}{|c|c|c|c|c|}
\hline \multirow{2}{*}{$\begin{array}{l}\text { Period after } \\
\text { adsorption } \\
\text { (hr.) }\end{array}$} & \multirow{2}{*}{$\begin{array}{l}\text { No. of } \\
\text { infected } \\
\text { cells } \\
(a)\end{array}$} & \multicolumn{2}{|c|}{ No. of virus particles } & \multirow{2}{*}{$\begin{array}{c}\% \text { infected } \\
\text { cells with } \\
\text { infectious virus* } \\
(100 b / a)\end{array}$} \\
\hline & & In eclipse & $\begin{array}{c}\text { Infectious* } \\
\text { (b) }\end{array}$ & \\
\hline 2 & 75 & 57 & 18 & 24 \\
\hline 5 & 78 & 48 & 30 & 38 \\
\hline $5 \cdot 5$ & 72 & 54 & 18 & 25 \\
\hline 6.5 & 96 & 81 & 15 & 15 \\
\hline 7 & 51 & 27 & 24 & 47 \\
\hline $7 \cdot 5$ & 99 & 69 & 30 & 30 \\
\hline 8 & 63 & 57 & 6 & 10 \\
\hline 9 & 81 & 51 & 30 & 37 \\
\hline 10 & 81 & 48 & 33 & 41 \\
\hline
\end{tabular}

* Infectious particles recovered on disintegrating the cells by ultrasonic vibrations during the eclipse phase.

that the infected cells remained viable and were capable of supporting virus replication on raising the temperature to $37^{\circ}$. By contrast, at $37^{\circ}$ the eclipse lasted $3-4 \mathrm{hr}$., and the 'uneclipsed' particles gradually decreased in number until the reappearance of infective virus at the end of the eclipse period masked the fate of the last few uneclipsed particles (Table 2). Thereafter the intracellular virus increased exponentially until a plateau was reached after 12-14 hr., with a yield of 700-1400 infectious 
Table 2. Poliovirus recovered from infected monkey kidney cells by ultrasonic disruption during the eclipse phase of replication at $37^{\circ}$

\begin{tabular}{|c|c|c|c|c|}
\hline \multirow{2}{*}{$\begin{array}{l}\text { Period after } \\
\text { adsorption } \\
(\mathbf{h r} .)\end{array}$} & \multirow{2}{*}{$\begin{array}{c}\text { *No. of } \\
\text { infected } \\
\text { cells } \\
(a)\end{array}$} & \multicolumn{2}{|c|}{ No. of virus particles } & \multirow{2}{*}{$\begin{array}{c}\% \text { infected } \\
\text { cells with } \\
\text { infectious virus } \\
(100 b / a)\end{array}$} \\
\hline & & In eclipse & $\begin{array}{c}\text { Infectious } \\
\text { (b) }\end{array}$ & \\
\hline $\mathbf{2}$ & 576 & 384 & 192 & 32 \\
\hline $2 \frac{1}{2}$ & 240 & 216 & 24 & 10 \\
\hline 3 & 216 & 192 & 24 & 11 \\
\hline $3 \frac{1}{2}$ & 180 & 171 & $\boldsymbol{9}$ & 5 \\
\hline 4 & 156 & . & 453 & $290 \dagger$ \\
\hline
\end{tabular}

* Summation of comparable experiments; medium at pH 7.0-7.4.

$\uparrow$ Eclipse ended.

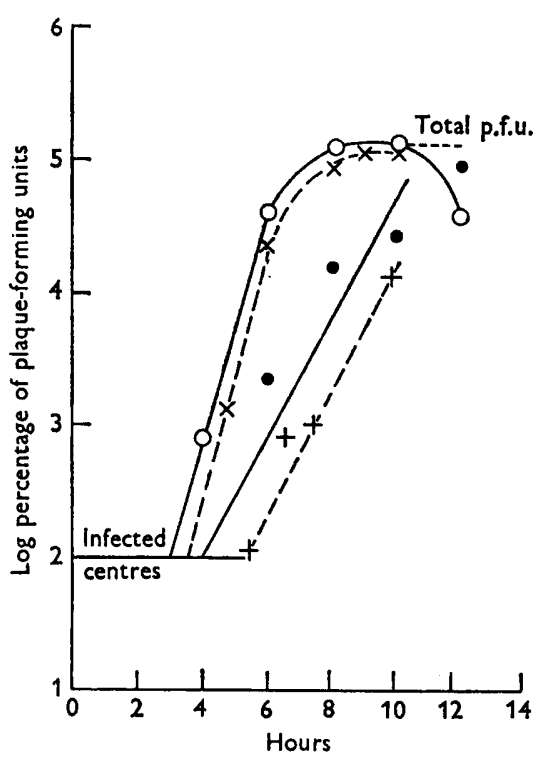

Fig. 1

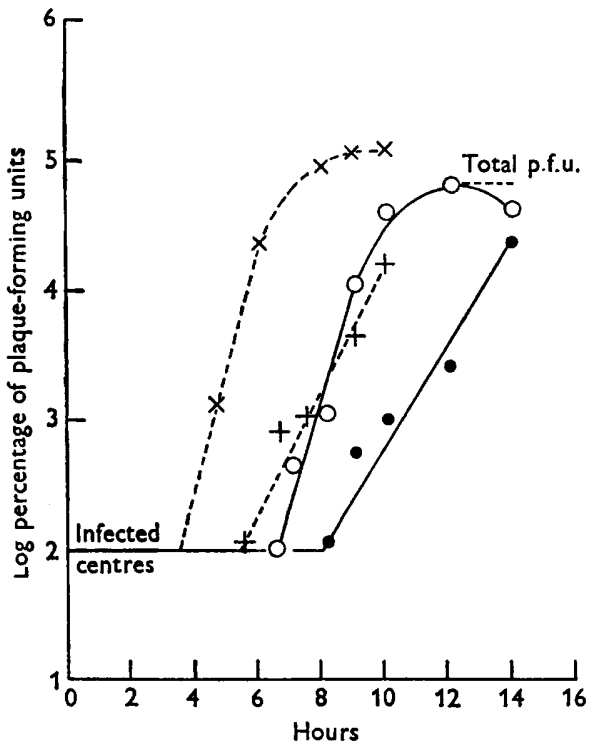

Fig. 2

Fig. 1. The effect of temperature of adsorption on the multiplication of poliovirus. $O-O$, intracellular p.f.u.; - - , extracellular p.f.u. adsorbed $25^{\circ}$. $\times \cdots \times$, intracellular p.f.u.; +-.+, extracellular p.f.u. adsorbed $37^{\circ}$.

Fig. 2. The effect of fluctuation in temperature of incubation on multiplication of poliovirus. $\times \cdots \times \times$, intracellular p.f.u.; $+\cdots+$, extracellular p.f.u. incubated $37^{\circ}$. $\mathrm{O}_{-} \mathrm{O}$, intracellular p.f.u.; - -

particles from each infected cell. Release began when the number of intracellular infectious particles reached approximately $10 \%$ of the total yield (Figs. 1, 2).

These results suggested that, with the exception of the uneclipsed particles, it would be possible to synchronize replication in all the cells by adsorbing at $25^{\circ}$ and then raising the temperature to $37^{\circ}$. However, although the virus particles adsorbed at $25^{\circ}$ remained capable of replication, the influence of the initial exposure at $25^{\circ}$ on the rate and extent of virus multiplication was unknown, and was accordingly studied. The technique was modified as follows. After adsorption of virus for $1 \mathrm{hr}$. 
at $25^{\circ}$, the monolayer was washed with $\mathrm{PB}$ saline at $25^{\circ}$ and the temperature raised to $37^{\circ}$ by adding EDTA saline at $37^{\circ}$ and maintained at that level. There was no significant difference between the multiplication of poliovirus after adsorption at $25^{\circ}$ and $37^{\circ}$ (Fig. 1).

The slight increase in the duration of the eclipse in cells throughout at $37^{\circ}$ is attributable to the method of computation; since virus adsorbed at $37^{\circ}$ begins to replicate during the adsorption period, zero time was taken as the time of adding the inoculum to the monolayer although, in fact, replication would not begin until the first particle had been adsorbed and gone into eclipse. At $25^{\circ}$ zero time was taken as the moment of raising the temperature to $37^{\circ}$. In this case, we know (Table 1) that replication does not begin until this moment; adsorption at $25^{\circ}$ therefore improves the method and has obvious advantages with viruses which are adsorbed slowly. The slight decrease in temperature below $37^{\circ}$, due to removal of the flask containing the virus cell suspension from the water bath to the bench for titration, affected the growth curve by increasing the eclipse period (Fig. 2), and by preventing the eclipse of uneclipsed particles (Table 3).

It is doubtful whether the slight variation in time of release is significant because

Table 3. Effect of fluctuations in temperature of incubation below $37^{\circ}$ on infectious particles recovered by ultrasonic disruption during the eclipse phase of replication

\begin{tabular}{|c|c|c|c|c|}
\hline \multirow{2}{*}{$\begin{array}{l}\text { Period after } \\
\text { adsorption } \\
\text { (hr.) }\end{array}$} & \multirow{2}{*}{$\begin{array}{l}\text { *No. of } \\
\text { infected } \\
\text { cells } \\
(a)\end{array}$} & \multicolumn{2}{|c|}{ No. of virus particles } & \multirow{2}{*}{$\begin{array}{c}\% \text { Infected } \\
\text { cells with } \\
\text { infectious virus } \\
(100 \mathrm{~b} / \mathrm{a})\end{array}$} \\
\hline & & In eclipse & $\begin{array}{c}\text { Infectious } \\
\text { (b) }\end{array}$ & \\
\hline 2 & 114 & 81 & 33 & 29 \\
\hline $4 \frac{1}{2}$ & 117 & 84 & 33 & 28 \\
\hline 5 & 117 & 99 & 18 & 15 \\
\hline $5 \frac{1}{2}$ & 108 & 75 & 33 & 30 \\
\hline 6 & 105 & 72 & 33 & 31 \\
\hline
\end{tabular}

Table 4. Influence of $\mathrm{pH}$ value of the medium on the eclipse stage of replication of poliovirus in suspensions of monkey kidney cells

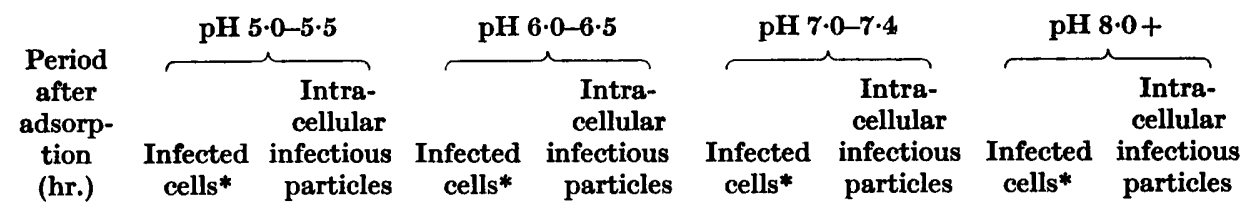

\begin{tabular}{|c|c|c|c|c|c|c|c|}
\hline 2 & 40 & 11 & • & . & 15 & 4 & 25 \\
\hline 3 & . & - & . & • & 10 & 1 & 27 \\
\hline 8.5 & . & . & • & . & . & . & 23 \\
\hline 4 & $\cdot$ & - & - & • & 10 & 31 & 9 \\
\hline 4.5 & . & . & . & . & - & . & 11 \\
\hline 5 & . & . & . & . & 12 & 400 & 13 \\
\hline $5 \cdot 5$ & 42 & 8 & 25 & 6 & . & - & . \\
\hline 6 & 42 & 6 & 23 & 40 & . & . & . \\
\hline 6.5 & 46 & 8 & 27 & 140 & . & . & . \\
\hline 7 & 37 & 10 & . & - & . & . & . \\
\hline 8 & 37 & $<10$ & . & . & • & • & • \\
\hline $\boldsymbol{9}$ & 38 & $<10$ & . & - & • & • & - \\
\hline
\end{tabular}


release occurred, as it did in other experiments, when $10 \%$ of the total progeny was formed. Moreover, there was no evidence that the lower yield/infected cell after adsorption at $25^{\circ}$ was a temperature effect.

\section{The effect of $\mathrm{pH}$}

Since the medium employed in these experiments was buffered with sodium bicarbonate, its $\mathrm{pH}$ value might have fluctuated during experiments. Replication of poliovirus in cell suspension was therefore studied by the present technique modified in that after adsorption at $\mathrm{pH} \mathbf{7 \cdot 0 - 7 \cdot 4}$ the diluted cell suspension was

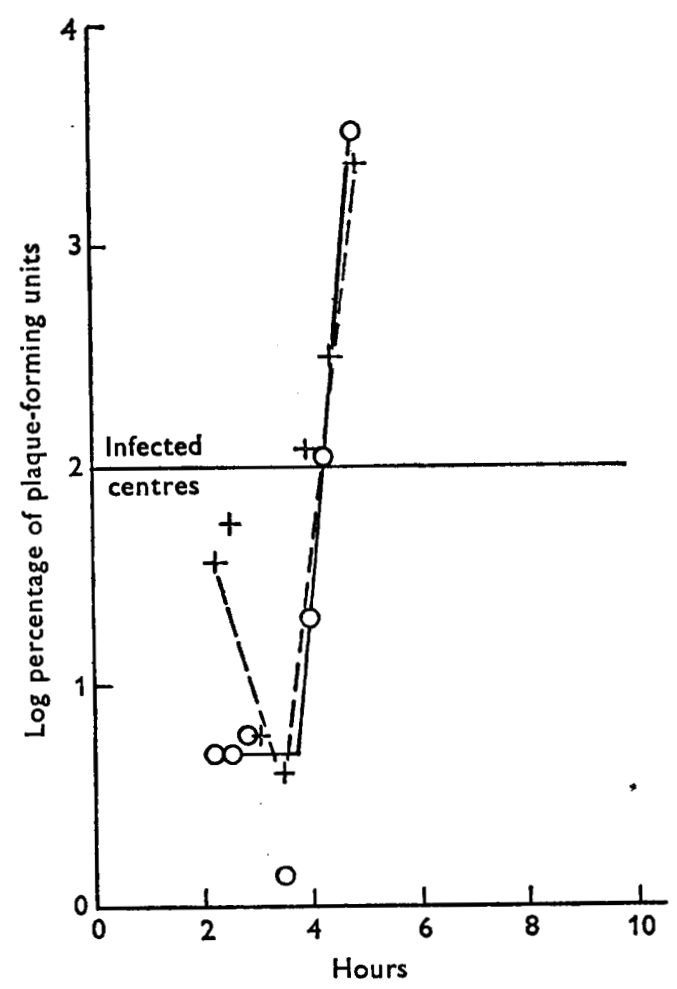

Fig. 3. The effect of antiserum on adsorbed infective particles recoverable by disrupting the cells. $\mathrm{O}-\mathrm{O}$, treated antiserum; $\times \cdots \times$, control.

prepared in rubber-stoppered flasks with media adjusted to the desired $\mathrm{pH}$ value by gassing with $\mathrm{CO}_{2}$. The $\mathrm{pH}$ value was estimated by the colour of the phenol red indicator and by $\mathrm{pH}$ papers. At $\mathrm{pH} 5 \cdot 0-5 \cdot 5$ poliovirus remained in eclipse for the duration of the experiment (9 hr.; Table 4). At pH 6.0-6.5, the eclipse lasted for $6 \mathrm{hr}$. and at $\mathrm{pH} 7 \cdot 0-7 \cdot 4$ for 3-4 hr. Above $\mathrm{pH} \mathrm{8.0} \mathrm{the} \mathrm{number} \mathrm{of} \mathrm{infected} \mathrm{cells}$ declined and the number of intracellular particles released by sonic vibrations varied between 0.04 and 3.7/cell, suggesting that in some cases virus had died and in others, that it had managed to replicate to a limited extent. The maintenance of a suitable $\mathrm{pH}$ value is, therefore, necessary to obtain reproducible results. 


\section{The error introduced by uneclipsed, non-replicating particles}

The synchronized replication of poliovirus that follows adsorption at $25^{\circ}$ does not of course affect the virus which fails to undergo eclipse. Nevertheless, the later non-synchronous replication of these particles confuses attempts to establish growth rates and virus yields in terms of the controlled conditions. An attempt was therefore made to inactivate these particles by neutralization with immune serum. Their susceptibility to antiserum was investigated as follows. An infected monolayer was dispersed in $3 \mathrm{ml}$. EDTA saline, and after adding $5 \mathrm{ml}$. medium 199, the cell suspension was divided into two parts. To $4 \mathrm{ml}$. was added $1 \mathrm{ml}$. antiserum and to the other $4 \mathrm{ml}$., $1 \mathrm{ml}$. medium as control. After incubation at $37^{\circ}$ for $30 \mathrm{~min}$. the suspensions were diluted in the usual manner, thereby rendering the residual antiserum ineffective, and the intracellular virus assayed by the present technique. The uneclipsed infectious particles were immediately decreased to $5 \%$ of the adsorbed virus by treatment with antiserum, whereas those in the control only reached a similar figure by the end of the eclipse phase (Fig. 3). There was no evidence that the remaining uneclipsed particles multiplied. Antiserum therefore inactivated most of the adsorbed virus which did not go into eclipse at $25^{\circ}$, and the technique of estimating synchronized replication was further improved.

\section{DISCUSSION}

Youngner (1956) first noted that poliovirus diffused through semi-solid agar overlay to initiate plaque formation in the underlying monkey kidney monolayers. McLaren et al. (1959) confirmed this observation but found that only $38 \%$ of the virus formed plaques. They also found, in tests of liquid suspensions of virus, that decreasing the volume of the inoculum increased the efficiency of adsorption. Our results show that all the virus in the overlay formed plaques when the volume of semi-solid agar in which the virus was suspended was decreased to a minimum. Maturation of the virus was also completed in single infected cells dispersed through the overlay, the virus progeny from each cell forming one plaque. Therefore, not only can the actual number of infected cells be estimated directly but the step of adsorbing the virus from liquid medium before covering with overlay is eliminated. This technique was used to study virus multiplication under conditions which virtually preclude multiple infection of the cells. The results emphasize the importance of optimal environmental conditions. One-step growth curves obtained under such conditions of temperature and $\mathrm{pH}$ agree with the results of other workers. The eclipse period lasted 3-4 hr.; thereafter intracellular virus progeny increased exponentially until a yield of 700-1400 infectious particles/cell was obtained after 12-14 hr. When the $\mathrm{pH}$ value of the medium was suboptimal for the cells, the eclipse was prolonged, a result which is complementary to the finding by Lwoff \& Lwoff (1960) that suboptimal pH values decrease the yield of poliovirus in K.B. cells. Suboptimal temperatures prolong the eclipse stage. The completion of virus maturation was not affected, the rate of replication at $37^{\circ}$ being the same after adsorption at $25^{\circ}$ or $37^{\circ}$. Adsorption at the lower temperature has been used to synchronize the replication of vaccinia virus, which requires a long adsorption period (Furness \& Youngner, $1959 a, b)$. This method could perhaps also be used to synchronize virus multiplica- 
tion in the investigation of interference phenomena, and in genetic recombination where multiple infection of cells with viruses having different adsorption periods might be desired. Low temperatures of incubation have obvious advantages when it is desired to slow or stop the processes of viral synthesis, as for example in the study of biochemical aspects of cell-virus interaction.

The writer wishes to thank Dr J. S. Youngner and his colleagues for their help and hospitality during his visit to the University of Pittsburgh. This work was supported by U.S. Public Health Service Grant No. E. 1707.

\section{REFERENCES}

Darnelu, J. E. (1958). Adsorption and maturation of poliovirus in singly and multiply infected HeLa cells. J. exp. Med. 107, 633.

Dulbecco, R. \& VoGt, M. (1955). Biological properties of poliomyelitis viruses as studied by the plaque technique. Ann. N.Y. Acad. Sci. 61, 790.

Furness, G. \& Youngner, J. S. $(1959 a)$. The replication of vaccinia virus in monkey kidney cell cultures. J. gen. Microbiol. 21, viii.

Furness, G. \& Youngner, J. S. (1959b). One-step growth curves for vaccinia virus in cultures of monkey kidney cells. Virology, 9, 386.

Howes, D. W. \& MELNICK, J. L. (1957). The growth cycle of poliovirus in monkey kidney cells. I. Maturation and release of virus in monolayers. Virology, 4, 97.

Lwoff, A., Dulbecco, R., Vogt, M. \& Lwoff, M. (1955). Kinetics of the release of poliomyelitis virus from single cells. Virology, 1, 128.

Lwoff, A. \& Lwoff, M. (1960). Sur les facteurs du développement viral et leur rôle dans l'évolution de l'infection. Ann. Inst. Pasteur, 98, 173.

MaAssab, H. F., Loh, P. C. \& AckermanN, W. W. (1957). Growth characteristics of poliovirus in HeLa cells. Nucleic acid metabolism. J. exp. Med. 106, 641.

Mclaren, L. C., Holland, J. J. \& Sxverton, J. T. (1959). The mammalian cell-virus relationship. I. Attachment of poliovirus to cultivated cells of primate and non-primate origin. J. exp. Med. 109, 475.

Youngner, J. S. (1954). Monolayer tissue cultures. I. Preparation and standardization of trypsin-dispersed monkey kidney cell suspensions. Proc. Soc. exp. Biol., N.Y. 85, 202.

YouNGNER, J. S. (1956). Virus adsorption and plaque formation in monolayer cultures of trypsin-dispersed monkey kidney. J. Immunol. 76, 288. 